\title{
Job Satisfaction in Federal Structure - A Case of Bhojpur, Nepal
}

\author{
Amrit Kumar Dahal*, Anjay Kumar Mishra**, Manoj Kumar Chaudhary***, \& P. S. \\ Aithal $* * * *$ \\ *Engineer, Province Government, Province No. 1, Infrastructure Development Office, \\ Bhojpur, Nepal; E-mail: ami10_25@hotmail.com \\ ***ost-Doctoral Research Scholar, Srinivas University, India and Associate Professor, \\ Madan Bhandari Memorial Academy Nepal, Urlabari3,Morang, Nepal \\ OrcidID: 0000-0003-2803-4918; Email: anjaymishra2000@ gmail.com \\ ***Associate Professor, Central Department of Management, Faculty of Management, \\ Tribhuvan University, Kathmandu, Nepal; E-mail: manoj.cdmtu.@ gmail.com \\ **** Professor, College of Management \& Commerce, Srinivas University, Mangalore, India \\ OrcidID: 0000-0002-4691-8736; E-mail: psaithal@gmail.com
}

Subject Area: Business Management.

Type of the Paper: Policy Research.

Type of Review: Peer Reviewed as per $|\mathrm{C}| \mathrm{O}|\mathrm{P}| \mathrm{E} \mid$ guidance.

Indexed In: OpenAIRE.

DOI: https://doi.org/10.5281/zenodo. 5496456

Google Scholar Citation: IJAEML

\section{How to Cite this Paper:}

Dahal, Amrit Kumar, Mishra, Anjay Kumar, Chaudhary, Manoj Kumar, \& Aithal, P. S., (2021). Job Satisfaction in Federal Structure - A Case of Bhojpur, Nepal. International Journal of Applied Engineering and Management Letters (IJAEML), 5(2), 38-56. DOI: https://doi.org/10.5281/zenodo.5496456

International Journal of Applied Engineering and Management Letters (IJAEML)

A Refereed International Journal of Srinivas University, India.

Crossref DOI : https://doi.org/10.47992/IJAEML.2581.7000.0102

(C) With Authors.

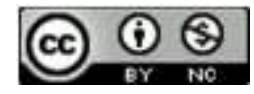

This work is licensed under a Creative Commons Attribution-Non-Commercial 4.0 International License subject to proper citation to the publication source of the work.

Disclaimer: The scholarly papers as reviewed and published by the Srinivas Publications (S.P.), India are the views and opinions of their respective authors and are not the views or opinions of the S.P. The S.P. disclaims of any harm or loss caused due to the published content to any party. 


\title{
Job Satisfaction in Federal Structure - A Case of Bhojpur, Nepal
}

\author{
Amrit Kumar Dahal*, Anjay Kumar Mishra**, Manoj Kumar Chaudhary***, \& P. S. \\ Aithal $* * * *$ \\ *Engineer, Province Government, Province No. 1, Infrastructure Development Office, \\ Bhojpur, Nepal; E-mail: ami10_25@hotmail.com \\ **Post-Doctoral Research Scholar, Srinivas University, India and Associate Professor, \\ Madan Bhandari Memorial Academy Nepal, Urlabari3,Morang, Nepal \\ OrcidID: 0000-0003-2803-4918; Email: anjaymishra2000@ gmail.com \\ ***Associate Professor, Central Department of Management, Faculty of Management, \\ Tribhuvan University, Kathmandu, Nepal; E-mail: manoj.cdmtu.@gmail.com \\ **** Professor, College of Management \& Commerce, Srinivas University, Mangalore, India \\ OrcidID: 0000-0002-4691-8736; E-mail: psaithal@gmail.com
}

\begin{abstract}
Purpose: The feelings that an employee have for the job is essential to be analyzed the job satisfaction level of government employees after implementation of federal state in the context of Bhojpur district of Nepal.

Design/Methodology/Approach: The questionnaire was distributed to governmental employees via mail and direct distribution to respective offices of Bhojpur district with 93.8\% of response rate. The data has been divided into local, provincial and federal categories and separately analyzed along with combined analysis too. Satisfaction level along with the factors of the same was accessed using SPSS for descriptive and inferential statistics.

Findings/Result: Government employees from all tiers of government viz. local, provincial and federal are dissatisfied with present remuneration, benefit and employee adjustment process along with present organizational structure, wage policy, present work performance evaluation system and decision-making system in offices but satisfied with present leave system after promulgation of federal structure. Present job authority and position are acceptable level for employees working in all three tiers of government. Most crucial factor seems to be promotion and career growth rather than remuneration. Job training, working environment, team spirit and right work performance evaluation system seem to be major parameters for job satisfaction. Job location is temporary in nature which can be easily handled. Strong reservation on promotion and job rotation approach which is included in new federal structure by all tiers of government employees.
\end{abstract}

Originality/Value: It is survey-based research to guide for amendment of present organizational structures and wage policy in new federal structure of Nepal.

Paper Type: Survey based Policy Research

Keywords: satisfaction, factors, effects, adjustment, act, wage policy, government employees

\section{INTRODUCTION :}

After the constitution of Promulgation of new constitution of Nepal, Government restructured system of state from central state to federalism. The Federal Democratic Republic of Nepal are mainly integrated in terms of the Federation, the State and the Local level (Government of Nepal, 2015) [1]. There was a need of restructuring civil services as per the new system to get optimum benefit to the geographically diversified people. For this, government brought Employee Adjustment Act 2017 which helped to adjust employees into three tiers of government. As per the Act government employees have had voluntary choice to select any of the three levels of government as per their suitability (Government of Nepal, 2017) [2]. To fulfill the outreach of development three tiers of governments has responsibility to quickly response the need for institutional and human capacity development. 
Employee Adjustment Act 2017 adjusted all the government employees by the end of July 2019 into Central, Provincial and Local Government. Data indicates that extra civil servants have been adjusted underneath the central authorities. An overall of 84,409 posts have been formed underneath vital government, 22,297 positions underneath the provincial governments and 66,908 positions below the 753 nearby ranges. The 35 in step with cent posts have been created for the centre, sixteen in step with cent posts for the provinces and forty-nine consistent with cent for the neighborhood stages.

In any case, 40,409 staff were changed in focus, 14,659 workers were changed inside the seven regions and 31,043 faculties had been changed inside the close by stages. This recommends that common governments and close by levels did now not get the necessary number of workers (The Himalayan Occasions, 2019) [3]. The circulate from a unitary to a federal shape of governance takes the "whole of presidency" technique that requires big reorientation of the institutions, structures, work cultures and patterns for smooth functioning. The horizontal and vertical traces of communication among the special degrees of presidency must set closer to powerful decentralization. After the hit elections and the oath taking ceremonies of the new sub-countrywide governments, there has been a growing call for services and development deliverables. As in keeping with constitution and new status quo, the authorities have made planning and price range making an investment inside the strengthening of establishments of governance. Deployment of the desired human sources, enhancing and constructing talents for making plans and service transport and aligning their strategic policies to orientate their organizational sources towards new duty is the alarming subject for newly fashioned governments.

Nepal faces a huge challenge in moving to a federal, secular and democratic kingdom. Federal technique has to make government greener and more receptive to the needs of the Nepalese humans. Access to great public services relies upon in large measure at the capabilities and motivation of the public employees who offer these services or oversee their activate shipping. A green worker management machine will be manner for improved motivation and effectiveness (Paudel, 2020) [4].

Government employees are the key elements to support government for the delivery of services and to implement the plan. In this changed context there is curiosity about satisfaction of government employees in different layers of government. So, this research tries to reveal the job satisfaction level of in civil services, its influencing factors and effects of employee adjustment in career development process in the initial stage of implementation of new federal constitution in Nepal. Employee satisfaction is a complete term which accommodates job delight of personnel and their pleasure usual with agencies" regulations, enterprise environment, etc (Sageer, Rafat, \& Agarwal, 2012) [5]. Employee pleasure is the terminology used to explain whether employees are happy, contended and pleasurable their desires and wishes at paintings. Many measures support that worker pleasure is a factor in worker motivation, employee purpose fulfillment and high-quality employee morale in the work area (More \& Padmanabhan, 2017) [6]. Satisfaction is one of the key elements that affect performance of an employee in government offices job. After the political change in 2008, government has decided to change the central government mechanism to federal state by political consensus in the parliament. All the government employees are adjusted to three tiers of government in changed federal structure in 2019 creating curiosity about their job satisfaction and performance in government organizations (Government of Nepal, 2017) [2].

Capacity of organization meets standards but lacks in performance as per assessment of A class Contractors in Nepal [7]. Budget is supported from foreign Aid as it has deficit in supply and demand in budget though government is intending for rapid development could be done through employee performance only [8] and [9]. Job satisfaction directly affects employees" performance and productivity. An efficient and effective bureaucracy and administration can deliver public services in a proper way. So, employee job satisfaction in different tiers of government is very interesting in the beginning stage. If satisfaction level is high success of concerned government and overall system delivery seems better and if dissatisfaction level is high there is chance of failure of concerned government which finally triggers for instability in the overall system. So, an extensive study about employee job satisfaction is very essential to enhance performance and make more stable for newly formed federal system by correcting loopholes and errors in the system.

\section{OBJECTIVES :}

The overall aim is to analyze the job satisfaction level of government civil servant after implementation of federal state in the context of Bhojpur district of Nepal. 


\section{LITERATURE REVIEW :}

\subsection{Conceptual Framework}

Salary, work culture, environment, merchandising obviously affect degree of process pleasure among employees. Therefore, those factors must be considered via an employer to growth the employees' level of process delight (Hong, Hamid, \&Salleh, 2013) [10]. Skills, motivation, satisfaction and rewards are large elements for job performance of worker. There is a sturdy relationship among abilities and personnel' overall performance. Trained personnel work with high performance. It increases the final output of the agency. Motivation is the important aspect for growing job overall performance at a place of work. Motivational factors inclusive of organizational weather, intensives, and trainings considered a fantastic motivator for the personnel. There is a great dating among financial rewards and personnel performance. If the overall performance is sponsored by using financial rewards, then employees' paintings more energetically on the painting's region. Rewards growth the personnel' commitment which in the long run consequences in good performance. Assigning monetary benefits result in the high-quality overall performance of personnel at paintings (Kumari, 2016) [11]. The factors which impact process pleasure are constrained private and profession growth, task traits, activity security, organizational assist, social courting inside organization, courting with immediately superior and so on. Different elements are associated with the task pride either undoubtedly or negatively. Low morale, false impression and decreased job delight can manifest if there is loss of communique. On the alternative hand, the belief of personnel that their pay or earnings is relatively or relatively low will instigate personnel' dissatisfaction at paintings too. By searching at the selected factors, a theoretical framework has been generated to signify the have an impact on of task stress, lack of communiqué and pay on process delight (Hee, Yan, Rizal, Kowang, \& Fei, 2018) [12].
Independent Variables
Dependent Variables

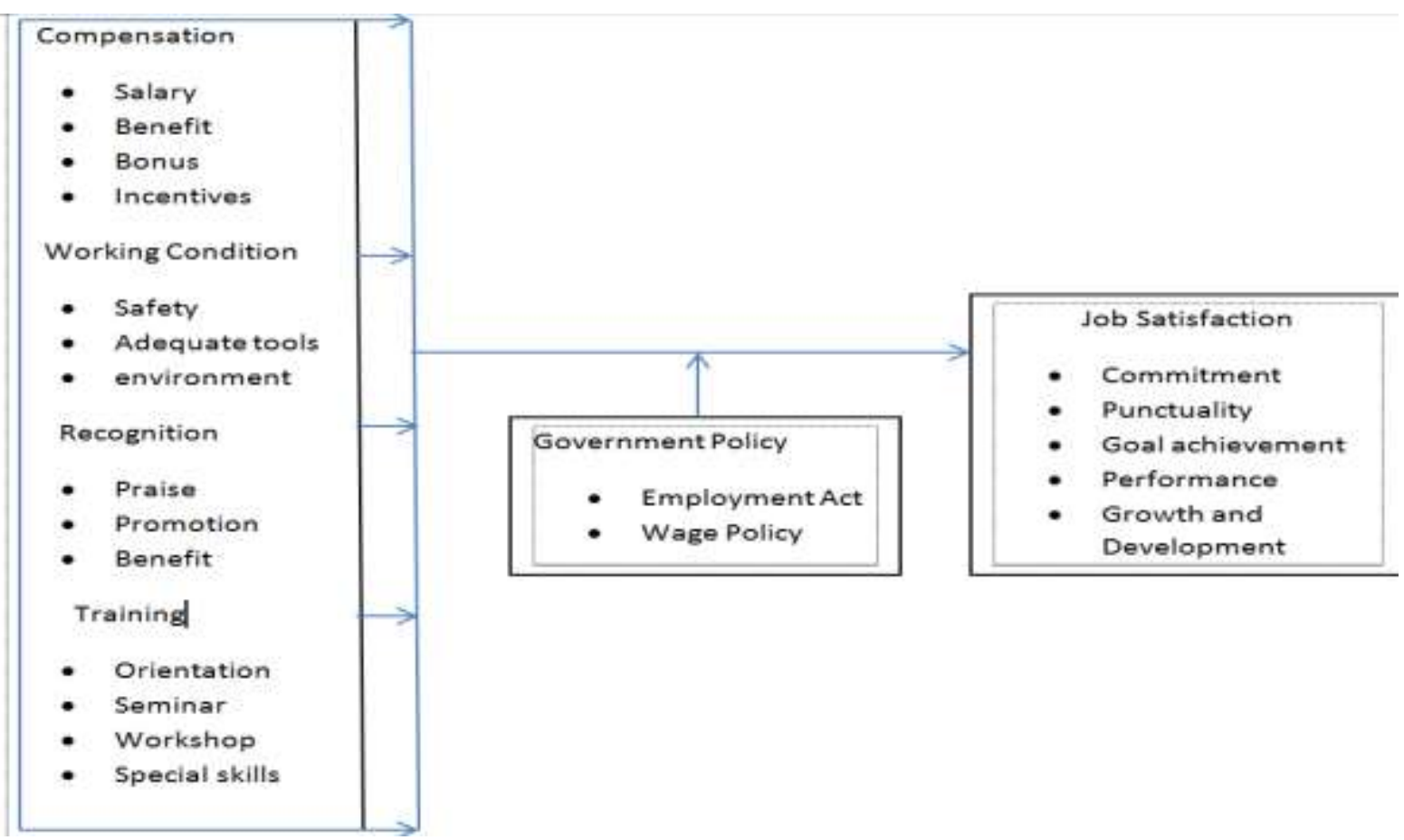

Fig. 1: Conceptual Framework for Job Satisfaction

\section{RESEARCH METHODOLOGY :}

\subsection{Study Area:}

Bhojpur is one of the 14 districts in Province No. 1 of Nepal which is situated in Eastern part. It is classified as hill district. It has nine local level government bodies with seven rural municipalities and two municipalities. It has thirteen provincial level offices and twenty-three central level offices situated in district. Offices include education, health, administration, development, small industry sector to provide service to public. The list of different governmental offices under study is listed in Table 1 . The 
population includes all the government offices in Bhojpur district of Nepal. Total number of government offices is Forty-Five in number.

Table 1; List of Government Offices under Study

\begin{tabular}{|c|c|c|c|c|}
\hline S.N. & $\begin{array}{l}\text { Nature of } \\
\text { government }\end{array}$ & Name of Office under Study & No. & Location \\
\hline \multirow{15}{*}{1} & \multirow{15}{*}{ Central Level } & District Administration Office & \multirow{15}{*}{15} & \multirow{15}{*}{ Bhojpur } \\
\hline & & District Co-ordination Committee & & \\
\hline & & District Level Project Implementation Unit & & \\
\hline & & District Education Co-ordination Office & & \\
\hline & & District Postal Office & & \\
\hline & & Nepal Electricity Authority & & \\
\hline & & Nepal Telecom & & \\
\hline & & Prime Minister Agriculture Research Centre & & \\
\hline & & Nepal Army & & \\
\hline & & Bhojpur Multiple Campus & & \\
\hline & & Agricultural Development Bank & & \\
\hline & & Rastriya Banijya Bank & & \\
\hline & & Nepal Bank Ltd. & & \\
\hline & & Department of Road Chakhewa-Bhojpur Project & & \\
\hline & & Financial Comptroller General Office & & \\
\hline \multirow{7}{*}{2} & \multirow{7}{*}{ Provincial Level } & Infrastructure Development Office & \multirow{7}{*}{7} & \multirow{7}{*}{ Bhojpur } \\
\hline & & Division Forest Office & & \\
\hline & & $\begin{array}{l}\text { Irrigation and Water Resources Development } \\
\text { Division }\end{array}$ & & \\
\hline & & District Hospital & & \\
\hline & & Ayurbed Kendra & & \\
\hline & & Water Supply and Sanitary Division & & \\
\hline & & Krishi Gyan Kendra & & \\
\hline \multirow{9}{*}{3} & \multirow{9}{*}{ Local Level } & Bhojpur Municipality & \multirow{9}{*}{9} & \multirow{9}{*}{ Bhojpur } \\
\hline & & Arun Rural Municipality & & \\
\hline & & Tyamke Maiyum Rural Municipality & & \\
\hline & & Aamchowk Rural Municipality & & \\
\hline & & Hatuwagadhi Rural Municipality & & \\
\hline & & Sadananda Municipality & & \\
\hline & & Salpa Silicho Rural Municipality & & \\
\hline & & Pauwadungma Rural Municipality & & \\
\hline & & Ram Prasad Rai Rural Municipality & & \\
\hline
\end{tabular}

(Field Survey, 2020) 


\subsection{Research Design:}

Descriptive just as causal relationship was investigated utilizing quantitative information examination to set up relationship of free factors with subordinate factors. Occupation fulfillment is reliant variable while compensation, professional stability, work revolution, wage strategy, and preparing are autonomous factors.

\subsection{Sampling:}

Managerial, schooling, wellbeing and improvement workplaces in commonplace and focal degree of government workplaces were covered from lower, center and high level applying defined arbitrary Testing.

Test size computation for respondents from different workplaces of neighborhood, commonplace and central government was determined by utilizing Cochranl's Equation. For illustration

$\mathrm{n}=\mathrm{Z}^{2 *} \mathrm{~N} * \mathrm{P} * \mathrm{Q} /\left(\mathrm{e}^{2}(\mathrm{~N}-1)+\mathrm{Z}^{2} * \mathrm{P} * \mathrm{Q}\right)($ Singh and Masuku, 2014) [13]

Where

$\mathrm{Z}=1.96$ (Value in $95 \%$ Confidence Level)

$\mathrm{N}=150$ (no. of employees under Central Government Offices in Bhojpur District

$\mathrm{P}=\mathrm{Q}=0.5$ (50\% probability each)

$\mathrm{e}=$ Standard Error $(5 \%$ assumed $)$

Sample Size $(\mathrm{n})=(1.96)^{2 *} 150 * 0.5 * 0.5 /\left((0.05)^{2 *}(150-1)+(1.96)^{2 *} 0.5 * 0.5\right)$

$$
\mathrm{n}=108
$$

The total number of respondents to conduct questionnaire survey is shown in table no.2.

Table 2 : Sample Size Calculation for Research

\begin{tabular}{|c|c|c|c|c|c|c|c|c|}
\hline $\mathbf{S}$ & $\begin{array}{c}\text { Nature of } \\
\text { Government }\end{array}$ & $\begin{array}{c}\text { Total } \\
\text { Office } \\
\text { s in } \\
\text { Distri } \\
\text { ct }\end{array}$ & $\begin{array}{c}\text { Offic } \\
\text { es } \\
\text { unde } \\
\mathbf{r} \\
\text { study }\end{array}$ & $\begin{array}{c}\text { Total } \\
\text { Employe } \\
\text { es } \\
\text { Populati } \\
\text { on under } \\
\text { Study(N) }\end{array}$ & $\begin{array}{c}\text { Sample } \\
\text { Responden } \\
\text { ts(n) }\end{array}$ & $\begin{array}{c}\text { Questionn } \\
\text { aire } \\
\text { Distribute } \\
\text { d }\end{array}$ & $\begin{array}{c}\text { Valid } \\
\text { Questionn } \\
\text { aire } \\
\text { Received }\end{array}$ & $\begin{array}{c}\text { Respon } \\
\text { dent } \\
\text { Percent } \\
\text { age }\end{array}$ \\
\hline 1 & Central Level & 23 & 15 & 150 & 108 & 120 & 110 & 91.67 \\
\hline 2 & $\begin{array}{c}\text { Provincial } \\
\text { Level }\end{array}$ & 13 & 7 & 60 & 52 & 58 & 54 & 93.10 \\
\hline 3 & Local Level & 9 & 9 & 90 & 73 & 80 & 78 & 97.50 \\
\hline & Total & 45 & 31 & 300 & 233 & 258 & 242 & 93.80 \\
\hline
\end{tabular}

In total Thirty-One government offices such as municipalities, rural municipality staffs and health, administrative, education and development offices of provincial level as well as central level government offices of Bhojpur district of Nepal were subjected for research project. Bottom level employees to top level employees were subjected to questionnaire survey to understand version of diversified employees.

\subsection{Method of Data Collection:}

Essential information was gathered by leading poll overview adding up to 200 and 42 respondents from all levels of government were exposed to survey study to clarify abstractly about information identified with work fulfillment in government workplaces.

\subsection{Data Examination:}

Poll review information were dissected by utilizing measurable devices, for example, Mean, Coconnection Investigation and were directed to build up relationship among different factors identified with work fulfillment. For the positioning of the variables, five-point Likert scale has been utilized and changed to relative significance records (RII) for each factor as follows (Somiah, 2015) [14]:

$$
\mathrm{RII}=\frac{\mathrm{SW}}{\mathrm{A}^{*} \mathrm{~N}}
$$

Where, 
$\mathrm{W}$ is the mentioned scale for rating a factor by the respondents which ranges from 1 to 5

$\mathrm{A}$ is the highest weight in the scale

$\mathrm{N}$ is the total number of respondents

\subsection{Reliability and Validity:}

The table 3 shows the ranges of Cronbach's alpha value and their internal consistency.

Table 3: Value of Cronbach's Alpha for Employee Job Satisfaction in Bhojpur District

\begin{tabular}{|c|c|c|c|}
\hline \multicolumn{4}{|c|}{ Reliability Statistics } \\
\hline Cronbach's Alpha & $\begin{array}{c}\text { Cronbach's Alpha Based } \\
\text { on Standardized Items }\end{array}$ & N of Items & $\begin{array}{c}\text { Internal } \\
\text { Consistency }\end{array}$ \\
\hline .663 & .755 & 30 & Acceptable \\
\hline
\end{tabular}

According to Cortina, the value of Cronbach's alpha value greater than 0.7 is acceptable and greater than 0.8 has considered good for reliability measure of research instrument (Cortina, 1993) [15].

\section{RESULTS AND DISCUSSION :}

\subsection{Present Job Satisfaction of Federal Employees}

Government job satisfaction is one of the indicators that show how government is delivering its service smoothly. Table 4 shows present job satisfaction level of government employees considering various parameters.

Table 4: Present Job Satisfaction Level of Federal Employees

\begin{tabular}{|l|c|c|c|c|c|}
\hline \multicolumn{7}{|c|}{ Descriptive Statistics } \\
\hline Salary and Benefit Scale & 110 & 1 & 5 & 2.8545 & 0.99389 \\
\hline $\begin{array}{l}\text { Present Working } \\
\text { Environment }\end{array}$ & 110 & 1 & 4 & 3 & 0.97679 \\
\hline Present Job Position & 110 & 1 & 5 & 3.1364 & 1.12092 \\
\hline Present Authority & 110 & 1 & 5 & 3.1727 & 0.98483 \\
\hline Present Job Rotation System & 110 & 1 & 5 & 2.7364 & 0.96429 \\
\hline $\begin{array}{l}\text { Present Work Performance } \\
\text { System }\end{array}$ & 110 & 1 & 5 & 2.4818 & 0.99293 \\
\hline $\begin{array}{l}\text { Present Decision-Making } \\
\text { System in Office }\end{array}$ & 110 & 1 & 5 & 2.8273 & 0.95648 \\
\hline Present Leave System & 110 & 1 & 5 & 3.4727 & 0.78646 \\
\hline $\begin{array}{l}\text { Present Organizational } \\
\text { Structure and Promotion } \\
\text { Mechanism }\end{array}$ & 110 & 1 & 5 & 2.4727 & 1.06409 \\
\hline $\begin{array}{l}\text { Present Overall Job } \\
\text { Satisfaction Level }\end{array}$ & 110 & 1 & 5 & 3.0818 & 0.89987 \\
\hline
\end{tabular}

(Field Survey, 2020) 
From Table 4, it shows that Federal employees are highly satisfied with present leave system crossing neutral level. Values of present working environment, present authority, present job position reaches to minimum acceptable level while present salary, present organizational structure and promotion mechanism, present job rotation system and present work performance evaluation system are below acceptable level. It shows that employees are dissatisfied with these parameters.

\subsection{Factors Affecting Job Satisfaction in Federal Employees}

There are different variables that influence work fulfillment of representatives. Table 5 shows boundaries influencing position fulfillment of Government officials.

Table 5: Variables influencing Job Satisfaction

\begin{tabular}{|l|c|c|}
\hline Factors Affecting Job Satisfaction & \multicolumn{2}{|c|}{ Federal } \\
\hline Promotion/Career Development & 0.935 & Ranking \\
\hline Job Training & 0.931 & 2 \\
\hline Working environment & 0.925 & 3 \\
\hline Team Spirit & 0.916 & 4 \\
\hline Job duty Evaluation System & 0.911 & 5 \\
\hline Communication with Senior Management & 0.907 & 6 \\
\hline Job Security & 0.904 & 7 \\
\hline Remuneration /Salary & 0.878 & 8 \\
\hline Work -Life Balance & 0.869 & 9 \\
\hline Organizational Structure & 0.869 & 9 \\
\hline Reward /Punishment Approach & 0.869 & 9 \\
\hline Stress Management & 0.864 & 12 \\
\hline Job rotation/relocation & 0.778 & 13 \\
\hline
\end{tabular}

(Field Survey, 2020)

From Table 5, it is seen that promotion and career development seems highly prioritized by federal employees followed by job training, working environment, team spirit and work performance evaluation system while job rotation system is least prioritized.

\subsection{Employee Adjustment Act and Federal Employees}

Representatives have communicated variant on worker change measure which was hung on 2018/19 A.D. Table 6 shows the information identified with it.

Table 6: Federal Officials' Perception on Employee Adjustment Act and Pay Policy

\begin{tabular}{|l|c|c|c|}
\hline & $\mathbf{N}$ & Mean & Std. Deviation \\
\hline Officials Adjustment Process & 110 & 2.7000 & .94384 \\
\hline $\begin{array}{l}\text { Amendment in inter province and } \\
\text { inter local level transfer }\end{array}$ & 110 & 3.9000 & .95735 \\
\hline Current Pay Increment System & 110 & 2.6091 & .98703 \\
\hline $\begin{array}{l}\text { Newly developed Organizational } \\
\text { frame }\end{array}$ & 110 & 2.6727 & .86850 \\
\hline
\end{tabular}




\begin{tabular}{|l|c|c|c|}
\hline Facilities of growth of Career in Act & 110 & 2.7727 & .93514 \\
\hline $\begin{array}{l}\text { Amendment in Promotion and Job } \\
\text { Rotation Approach }\end{array}$ & 110 & 3.9909 & .84044 \\
\hline $\begin{array}{l}\text { Amendment in current Organizational } \\
\text { Structure and Remuneration-Pay } \\
\text { Policy }\end{array}$ & 110 & 4.1818 & .73174 \\
\hline
\end{tabular}

(Field Survey, 2020)

From Table 6, it has been revealed that Federal employees are dissatisfied with employee adjustment process. Only mean value of 2.7 has been found showing dissatisfaction over government's employee adjustment process. They are dissatisfied with present organizational structure, present salary and its increment system and expressed worries about promotion mechanism. They are in favor of amendment in promotion and job rotation approach and also expressed verdict to change present organizational structure and wage policy garnering 4.18 as mean value.

\subsection{Analysis of Provincial Employees}

As per the objective analysis of Provincial Level Employees has been presented below.

\subsubsection{Present Job Satisfaction of Provincial Employees}

Government job satisfaction is one of the indicators that show how government is delivering its service smoothly. Table 7 shows present job satisfaction level of government employees considering various parameters.

Table 7: Present Job Satisfaction Level of Provincial Employees

\begin{tabular}{|l|r|r|r|}
\hline & N & \multicolumn{1}{|c|}{ Mean } & \multicolumn{1}{|c|}{ Std. Deviation } \\
\hline Salary and Benefit Scale & 54 & 2.8148 & .99193 \\
\hline Present Working Environment & 54 & 2.9815 & .99983 \\
\hline Present Job Position & 54 & 3.5741 & .96352 \\
\hline Present Authority & 54 & 3.3333 & .91115 \\
\hline Present Job Rotation System & 54 & 2.7222 & .99843 \\
\hline Present Work Performance System & 54 & 2.9444 & .99843 \\
\hline $\begin{array}{l}\text { Present Decision-Making System in } \\
\text { Office }\end{array}$ & 54 & 3.2222 & .86147 \\
\hline Present Leave System & 54 & 3.6296 & .80789 \\
\hline $\begin{array}{l}\text { Present Organizational Structure and } \\
\text { Promotion Mechanism }\end{array}$ & 54 & 2.7407 & 1.06727 \\
\hline Present Overall Job Satisfaction Level & & & .87775 \\
\hline
\end{tabular}

(Field Survey, 2020)

Table 4-4 shows that provincial employees are satisfied with present government leave system with 3.6 mean values. Likewise, present authority, present job position; present decision-making system is acceptable in nature crossing 3.00 as mean value. It is to note that present haphazard job rotation system and present organizational structure is not in satisfactory level as per perspective from provincial employees. 


\subsubsection{Factors Affecting Job Satisfaction in Provincial Employees}

There are various factors that influence work fulfillment of representatives. Table 8 shows boundaries influencing position fulfillment of Common Representatives. Relative Significance Record has been taken as key pointer for estimation of occupation influencing factors.

Table 8: Factors Influencing Job Satisfaction of Provincial officers

\begin{tabular}{|l|c|c|}
\hline \multicolumn{1}{|c|}{ Factors Influencing Job Satisfaction } & \multicolumn{2}{c|}{ Provincial } \\
\hline Promotion/Career Development & RII & Ranking \\
\hline Working environment & 0.937 & 1 \\
\hline Job Training & 0.93 & 2 \\
\hline Team Spirit & 0.919 & 3 \\
\hline Remuneration /Salary & 0.919 & 3 \\
\hline Work Performance Evaluation System & 0.911 & 5 \\
\hline Job Security & 0.9 & 6 \\
\hline Work -Life Balance & 0.896 & 7 \\
\hline Organizational Structure & 0.896 & 7 \\
\hline Communication with Senior Management & 0.885 & 9 \\
\hline Stress Management & 0.881 & 10 \\
\hline Reward /Punishment Approach & 0.874 & 11 \\
\hline Job rotation/relocation & 0.867 & 12 \\
\hline
\end{tabular}

(Field Survey, 2020)

Table 8 shows that Advancement and profession improvement is the principle influencing factor getting position 1 with RII esteem 0.937. Other significant influencing factors are working climate, work preparing, camaraderie, and compensation individually. Occupation pivot, reward/discipline approach and stress the board are least focused on by common representatives.

\subsubsection{Employee Adjustment Act and Provincial Employees}

Officials' perception on their adjustment process is shown in Table 9.

Table 9: Provincial Employees' perception on Employee Adjustment Act and Wage Policy

\begin{tabular}{|l|c|c|c|}
\hline & N & Mean & Std. Deviation \\
\hline Officials Adjustment Process & 54 & 2.8333 & 1.04159 \\
\hline $\begin{array}{l}\text { Amendment in inter province and inter local } \\
\text { level transfer }\end{array}$ & 54 & 4.1481 & .78686 \\
\hline Current Pay Increment System & 54 & 2.5741 & 1.05691 \\
\hline Newly developed Organizational frame & 54 & 2.9259 & .94872 \\
\hline Facilities of growth of Career in Act & 54 & 3.7593 & 5.68326 \\
\hline $\begin{array}{l}\text { Amendment in Promotion and Job Rotation } \\
\text { Approach }\end{array}$ & 54 & 4.1667 & .79503 \\
\hline
\end{tabular}


Amendment in current Organizational Structure and Remuneration-Pay Policy 54

(Field Survey, 2020)

From Table 9, it tends to be uncovered that commonplace worker are not happy with representative change measure. From the mean worth it has been seen that alteration in present hierarchical design and compensation strategy (4.35), amendment in advancement and occupation revolution approach (4.16) and correction in entomb area and bury nearby level exchange (4.14) is exceptionally focused on by commonplace level representatives.

\subsection{Analysis of Local Employees}

The analysis of Local Level Employees has been presented below.

\subsubsection{Present Job Satisfaction of Local Employees}

Government job satisfaction is one of the indicators that show how government is delivering its service smoothly. Table 10 shows present job satisfaction level of government employees considering various parameters.

Table 10: Present Job Satisfaction Level of Local Employees

\begin{tabular}{|l|l|l|l|}
\hline & N & Mean & Std. Deviation \\
\hline Salary and Benefit Scale & 78 & 2.7564 & 1.03429 \\
\hline Present Working Environment & 78 & 2.7564 & 1.05911 \\
\hline Present Job Position & 78 & 3.0128 & 1.03815 \\
\hline Present Authority & 78 & 3.0897 & 0.99591 \\
\hline Present Job Rotation System & 78 & 2.8718 & 1.01109 \\
\hline Present Work Performance System & 78 & 2.8846 & 1.03171 \\
\hline $\begin{array}{l}\text { Present Decision-Making System in } \\
\text { Office }\end{array}$ & 78 & 2.9487 & 0.99214 \\
\hline Present Leave System & 78 & 3.4615 & 0.94926 \\
\hline $\begin{array}{l}\text { Present Organizational Structure and } \\
\text { Promotion Mechanism }\end{array}$ & 78 & 2.7051 & 1.02068 \\
\hline Present Overall Job Satisfaction Level & 78 & 2.8205 & 0.90802 \\
\hline
\end{tabular}

(Field Survey, 2020)

Table 10 shows that provincial employees are satisfied with present government leave system with 3.46 mean values. Likewise, present authority, present job position is acceptable in nature crossing 3.00 as mean value. It is to note that present haphazard job rotation system, present salary, present working environment and present organizational structure is not in satisfactory level as per perspective from local employees.

\subsubsection{Factors Affecting Job Satisfaction in Local Employees}

There are various factors that influence work fulfillment of representatives. Same as Table 8, in table 11 influencing factor of job satisfaction in local level employee is presented. 
Table 11: Factors Affecting Job Satisfaction of Local Employees

\begin{tabular}{|l|c|c|}
\hline Factors Affecting Job Satisfaction & \multicolumn{2}{|c|}{ Local } \\
\hline Promotion/Career Development & RII & Ranking \\
\hline Job Training & 0.928 & 1 \\
\hline Team Spirit & 0.926 & 2 \\
\hline Communication with Senior Management & 0.923 & 3 \\
\hline Work -Life Balance & 0.921 & 4 \\
\hline Working environment & 0.915 & 5 \\
\hline Work Performance Evaluation System & 0.913 & 6 \\
\hline Job Security & 0.913 & 6 \\
\hline Organizational Structure & 0.913 & 6 \\
\hline Remuneration /Salary & 0.892 & 9 \\
\hline Stress Management & 0.887 & 10 \\
\hline Reward/Punishment Approach & 0.864 & 11 \\
\hline Job rotation/relocation & 0.854 & 12 \\
\hline
\end{tabular}

(Field Survey, 2020)

Table 11 shows that Advancement and vocation improvement is the primary influencing factor getting position 1 with RII esteem 0.928 . Other significant influencing factors are work preparing, solidarity, and correspondence with senior administration, balance between fun and serious activities individually. Occupation pivot, reward/discipline approach and stress the board are least focused on by nearby workers.

\subsubsection{Employee Adjustment Act and Local Level officers}

The perception of local level officials has been presented in Table 12 on Adjust Act and Pay Policy.

Table 12: Local Employees' Version on Employee Adjustment Act and Wage Policy

\begin{tabular}{|l|c|c|c|}
\hline & N & Mean & Std. Deviation \\
\hline Officials Adjustment Process & 78 & 2.9103 & 1.04677 \\
\hline $\begin{array}{l}\text { Amendment in inter province and } \\
\text { inter local level transfer }\end{array}$ & 78 & 4.1538 & .80706 \\
\hline Current Pay Increment System & 78 & 2.8718 & 1.08543 \\
\hline $\begin{array}{l}\text { Newly developed Organizational } \\
\text { frame }\end{array}$ & 78 & 2.9872 & .88997 \\
\hline $\begin{array}{l}\text { Facilities of growth of Career in Act } \\
\text { Rotation Approach }\end{array}$ & 78 & 3.0513 & .95206 \\
\hline
\end{tabular}




$$
\begin{aligned}
& \text { Amendment in current Organizational } \\
& \text { Structure and Remuneration-Pay } \\
& \text { Policy }
\end{aligned}
$$

4.0641

.76174

(Field Survey, 2020)

From Table 12 It tends to be uncovered that neighborhood representatives are not happy with worker change measure with mean worth 2.91 as it were. From the mean worth it has been seen that change in present hierarchical design and pay strategy (4.06), amendment in advancement and occupation pivot approach (4.11) and revision in entomb region and bury nearby level exchange (4.15) is profoundly focused on by neighborhood level workers.

\subsection{Analysis of Overall Employees}

The analysis of Overall Employees has been presented below.

\subsubsection{Present Job Satisfaction of Overall Employees}

Government job satisfaction is one of the indicators that show how government is delivering its service smoothly. Table 13 shows present job satisfaction level of government employees considering various

\begin{tabular}{|c|c|c|c|}
\hline & $\mathbf{N}$ & Mean & Std. Deviation \\
\hline Salary and Benefit Scale & 242 & 2.8140 & 1.00338 \\
\hline Present Working Environment & 242 & 2.9174 & 1.01103 \\
\hline Present Job Position & 242 & 3.1942 & 1.07763 \\
\hline Present Authority & 242 & 3.1818 & .97266 \\
\hline Present Job Rotation System & 242 & 2.7769 & .98527 \\
\hline Present Work Performance System & 242 & 2.7149 & 1.02525 \\
\hline $\begin{array}{l}\text { Present Decision-Making System in } \\
\text { Office }\end{array}$ & 242 & 2.9545 & .95652 \\
\hline Present Leave System & 242 & 3.5041 & .84602 \\
\hline $\begin{array}{l}\text { Present Organizational Structure and } \\
\text { Promotion Mechanism }\end{array}$ & 242 & 2.6074 & 1.05395 \\
\hline Present Overall Job Satisfaction Level & 242 & 3.0413 & .91003 \\
\hline
\end{tabular}
parameters.

Table 13: Present Job Satisfaction Level of Overall Employees

(Field Survey, 2020)

Table 13 shows that overall employees are satisfied with present government leave system with 3.5 mean values. Likewise, present authority (3.18), present job position (3.19) and present job satisfaction level (3.04) are just acceptable in nature crossing 3.00 as mean value. It is to note that present haphazard job rotation system (2.77), present salary (2.81), present working environment (2.91) present decisionmaking system (2.95) and present organizational structure (2.60) is not in satisfactory level as per perspective from all employees.

\subsubsection{Factors Affecting Job Satisfaction in Overall Employees}

There are various factors that influences job satisfaction of officials is shown in Table 14. 
Table 14: Factors Influencing Job Satisfaction of Overall officials

\begin{tabular}{|c|c|c|c|c|c|c|c|c|}
\hline \multirow[t]{2}{*}{$\begin{array}{l}\text { Factors Affecting Job } \\
\text { Satisfaction }\end{array}$} & \multicolumn{2}{|c|}{ Federal } & \multicolumn{2}{|c|}{ Provincial } & \multicolumn{2}{|c|}{ Local } & \multicolumn{2}{|c|}{ Overall } \\
\hline & RII & $\begin{array}{c}\operatorname{Ran} \\
\mathbf{k}\end{array}$ & RII & $\begin{array}{c}\operatorname{Ran} \\
\mathbf{k}\end{array}$ & RII & $\begin{array}{c}\operatorname{Ran} \\
\mathbf{k}\end{array}$ & RII & $\begin{array}{c}\text { Ran } \\
\mathbf{k}\end{array}$ \\
\hline Promotion/Career Development & 0.935 & 1 & 0.94 & 1 & 0.928 & 1 & $\begin{array}{c}0.93 \\
3\end{array}$ & 1 \\
\hline Job Training & 0.931 & 2 & 0.92 & 3 & 0.926 & 2 & $\begin{array}{c}0.92 \\
6\end{array}$ & 2 \\
\hline Working environment & 0.925 & 3 & 0.93 & 2 & 0.913 & 6 & $\begin{array}{c}0.92 \\
2\end{array}$ & 3 \\
\hline Team Spirit & 0.916 & 4 & 0.92 & 3 & 0.923 & 3 & $\begin{array}{c}0.91 \\
9\end{array}$ & 4 \\
\hline Job Evaluation System & 0.911 & 5 & 0.9 & 6 & 0.913 & 6 & $\begin{array}{c}0.90 \\
9\end{array}$ & 5 \\
\hline $\begin{array}{l}\text { Communication with Senior } \\
\text { Management }\end{array}$ & 0.907 & 6 & 0.88 & 10 & 0.921 & 4 & $\begin{array}{c}0.90 \\
6\end{array}$ & 6 \\
\hline Job Security & 0.904 & 7 & 0.9 & 7 & 0.913 & 6 & $\begin{array}{c}0.90 \\
5\end{array}$ & 7 \\
\hline Work -Life Balance & 0.869 & 9 & 0.9 & 7 & 0.915 & 5 & $\begin{array}{c}0.89 \\
0\end{array}$ & 8 \\
\hline Remuneration /Salary & 0.878 & 8 & 0.91 & 5 & 0.887 & 10 & $\begin{array}{c}0.88 \\
3 \\
\end{array}$ & 9 \\
\hline Organizational Structure & 0.869 & 9 & 0.89 & 9 & 0.892 & 9 & $\begin{array}{c}0.88 \\
0\end{array}$ & 10 \\
\hline Stress Management & 0.864 & 12 & 0.87 & 11 & 0.864 & 11 & $\begin{array}{c}0.86 \\
6\end{array}$ & 11 \\
\hline Reward /Punishment Approach & 0.869 & 9 & 0.87 & 12 & 0.854 & 12 & $\begin{array}{c}0.86 \\
4 \\
\end{array}$ & 12 \\
\hline Job rotation/relocation & 0.778 & 13 & 0.82 & 13 & 0.823 & 13 & $\begin{array}{c}0.80 \\
2\end{array}$ & 13 \\
\hline
\end{tabular}

(Field Survey, 2020)

Table 14 shows that Advancement and profession improvement is the principle influencing factor getting position 1 with RII esteem 0.933. Other significant influencing factors are work preparing $(\mathrm{RII}=0.926)$, working climate $(\mathrm{RII}=0.922)$ cooperation $(\mathrm{RII}=0.919)$, work execution assessment framework $(\mathrm{RII}=0.909)$. Occupation revolution, reward/discipline approach, stress the board and authoritative construction are least focused on by government workers.

\subsubsection{Measurement of Correlation of Job Satisfaction and its Variables}

The Pearson correlation coefficients between nine job related factors as independent variable and job satisfaction by summation job factors method as dependent variable were determined by analyzing the primary survey data in SPSS. Correlation coefficient values and their significance were presented in Table 15. 
Table 15: Correlation Coefficients between Jobs related Variables and Job Satisfaction

\begin{tabular}{|c|c|c|c|c|c|c|c|c|c|c|c|c|c|c|}
\hline & & $\begin{array}{c}\text { Remu } \\
\text { nerati } \\
\text { on }\end{array}$ & $\begin{array}{c}\text { Job } \\
\text { Sec } \\
\text { urit } \\
y\end{array}$ & $\begin{array}{c}\text { Promot } \\
\text { ion/Car } \\
\text { eer } \\
\text { Develo } \\
\text { pment }\end{array}$ & $\begin{array}{l}\text { Job } \\
\text { Tra } \\
\text { ini } \\
\text { ng }\end{array}$ & $\begin{array}{c}\text { W } \\
\text { ork } \\
\text { Lif } \\
\text { e } \\
\text { Bal } \\
\text { anc } \\
\text { e }\end{array}$ & $\begin{array}{c}\text { Job } \\
\text { rotation/ } \\
\text { Relocati } \\
\text { on }\end{array}$ & $\begin{array}{l}\text { Work } \\
\text { ing } \\
\text { Envir } \\
\text { ionm } \\
\text { ent }\end{array}$ & $\begin{array}{c}\text { Organ } \\
\text { izatio } \\
\text { nal } \\
\text { Struct } \\
\text { ure }\end{array}$ & $\begin{array}{c}\text { Te } \\
\mathrm{a} \\
\mathrm{m} \\
\mathrm{Sp} \\
\text { iri } \\
\mathrm{t}\end{array}$ & $\begin{array}{c}\text { Rew } \\
\text { ard- } \\
\text { Puni } \\
\text { shm } \\
\text { ent } \\
\text { Appr } \\
\text { oach }\end{array}$ & $\begin{array}{l}\text { Stres } \\
\text { s } \\
\text { Mana } \\
\text { geme } \\
\text { nt }\end{array}$ & $\begin{array}{l}\text { Comm } \\
\text { unicati } \\
\text { on } \\
\text { with } \\
\text { Senior } \\
\text { Manag } \\
\text { ement }\end{array}$ & $\begin{array}{c}\text { Wor } \\
\mathrm{k} \\
\text { Perfo } \\
\text { rman } \\
\text { ce } \\
\text { Eval } \\
\text { uatio } \\
\mathrm{n} \\
\text { Syste } \\
\mathrm{m}\end{array}$ \\
\hline \multirow[t]{3}{*}{$\begin{array}{l}\text { Remune } \\
\text { ration }\end{array}$} & $\begin{array}{l}\text { Pear } \\
\text { son } \\
\text { Corr } \\
\text { elati } \\
\text { on } \\
\end{array}$ & 1 & $\begin{array}{l}.50 \\
5^{* *}\end{array}$ & $.219^{* *}$ & $\begin{array}{l}.32 \\
6^{* *}\end{array}$ & $\begin{array}{l}.17 \\
8^{* * *}\end{array}$ & .105 & $.165^{*}$ & .101 & $\begin{array}{r}.1 \\
38 \\
*\end{array}$ & $\begin{array}{r}.226^{*} \\
*\end{array}$ & $\begin{array}{r}.330^{*} \\
*\end{array}$ & $.207^{* *}$ & \\
\hline & $\begin{array}{l}\text { Sig. } \\
(2- \\
\text { taile } \\
\text { d) }\end{array}$ & & $\begin{array}{r}.00 \\
0\end{array}$ & .001 & $\begin{array}{r}.00 \\
0\end{array}$ & $\begin{array}{r}.00 \\
5\end{array}$ & .102 & .010 & .119 & $\begin{array}{r}.0 \\
32\end{array}$ & .000 & .000 & .001 & .000 \\
\hline & $\mathrm{N}$ & 242 & $\begin{array}{r}24 \\
2 \\
\end{array}$ & 242 & 242 & $\begin{array}{r}24 \\
2 \\
\end{array}$ & 242 & 242 & 242 & $\begin{array}{r}24 \\
2 \\
\end{array}$ & 242 & 242 & 242 & 242 \\
\hline \multirow[t]{3}{*}{$\begin{array}{l}\text { Job } \\
\text { Security }\end{array}$} & $\begin{array}{l}\text { Pear } \\
\text { son } \\
\text { Corr } \\
\text { elati } \\
\text { on }\end{array}$ & $.505^{* *}$ & 1 & $.256^{* *}$ & $\begin{array}{l}.27 \\
7^{* *}\end{array}$ & $\begin{array}{r}.16 \\
3^{*}\end{array}$ & .042 & $.260^{* * *}$ & .100 & $\begin{array}{r}.2 \\
38 \\
* *\end{array}$ & $\begin{array}{r}.209^{*} \\
*\end{array}$ & $.334_{*}^{*}$ & .107 & $\begin{array}{r}.175^{*} \\
*\end{array}$ \\
\hline & $\begin{array}{l}\text { Sig. } \\
(2- \\
\text { taile } \\
\text { d) }\end{array}$ & .000 & & .000 & $\begin{array}{r}.00 \\
0\end{array}$ & $\begin{array}{r}.01 \\
1\end{array}$ & .511 & .000 & .122 & $\begin{array}{r}.0 \\
00\end{array}$ & .001 & .000 & .097 & .006 \\
\hline & $\mathrm{N}$ & 242 & $\begin{array}{r}24 \\
2\end{array}$ & 242 & 242 & $\begin{array}{r}24 \\
2\end{array}$ & 242 & 242 & 242 & $\begin{array}{r}24 \\
2\end{array}$ & 242 & 242 & 242 & 242 \\
\hline \multirow[t]{3}{*}{$\begin{array}{l}\text { Promoti } \\
\text { on/Care } \\
\text { er } \\
\text { Develop } \\
\text { ment }\end{array}$} & $\begin{array}{l}\text { Pear } \\
\text { son } \\
\text { Corr } \\
\text { elati } \\
\text { on }\end{array}$ & $.219^{* * *}$ & $\begin{array}{l}.25 \\
6^{* *}\end{array}$ & 1 & $\begin{array}{l}.37 \\
8^{* *}\end{array}$ & $\begin{array}{l}.25 \\
6^{* *}\end{array}$ & $.234^{* * *}$ & $.340^{* *}$ & .089 & $\begin{array}{r}.2 \\
51 \\
* * *\end{array}$ & $\begin{array}{r}.176^{*} \\
*\end{array}$ & $.273^{*}$ & $.236^{* *}$ & $\begin{array}{r}.318^{*} \\
*\end{array}$ \\
\hline & $\begin{array}{l}\text { Sig. } \\
(2- \\
\text { taile } \\
\text { d) }\end{array}$ & .001 & $\begin{array}{r}.00 \\
0\end{array}$ & & $\begin{array}{r}.00 \\
0\end{array}$ & $\begin{array}{r}.00 \\
0\end{array}$ & .000 & .000 & .167 & $\begin{array}{r}.0 \\
00\end{array}$ & .006 & .000 & .000 & .000 \\
\hline & $\mathrm{N}$ & 242 & $\begin{array}{r}24 \\
2\end{array}$ & 242 & 242 & $\begin{array}{r}24 \\
2\end{array}$ & 242 & 242 & 242 & $\begin{array}{r}24 \\
2\end{array}$ & 242 & 242 & 242 & 242 \\
\hline \multirow[t]{3}{*}{$\begin{array}{l}\text { Job } \\
\text { Trainin } \\
\mathrm{g}\end{array}$} & $\begin{array}{l}\text { Pear } \\
\text { son } \\
\text { Corr } \\
\text { elati } \\
\text { on }\end{array}$ & $.326^{* * *}$ & $\begin{array}{l}.27 \\
7^{* *}\end{array}$ & $.378^{* *}$ & 1 & $\begin{array}{l}.30 \\
9^{* * *}\end{array}$ & $.204^{* *}$ & $.395^{* *}$ & .111 & $\begin{array}{r}.2 \\
52 \\
* *\end{array}$ & $.271_{*}^{*}$ & $\begin{array}{r}.380^{*} \\
*\end{array}$ & $.315^{* *}$ & $\begin{array}{r}.381_{*}^{*} \\
*\end{array}$ \\
\hline & $\begin{array}{l}\text { Sig. } \\
(2- \\
\text { taile } \\
\text { d) }\end{array}$ & .000 & $\begin{array}{r}.00 \\
0\end{array}$ & .000 & & $\begin{array}{r}.00 \\
0\end{array}$ & .001 & .000 & .085 & $\begin{array}{r}.0 \\
00\end{array}$ & .000 & .000 & .000 & .000 \\
\hline & $\mathrm{N}$ & 242 & $\begin{array}{r}24 \\
2\end{array}$ & 242 & 242 & $\begin{array}{r}24 \\
2\end{array}$ & 242 & 242 & 242 & $\begin{array}{r}24 \\
2\end{array}$ & 242 & 242 & 242 & 242 \\
\hline \multirow[t]{3}{*}{$\begin{array}{l}\text { Work } \\
\text { Life } \\
\text { Balance }\end{array}$} & $\begin{array}{l}\text { Pear } \\
\text { son } \\
\text { Corr } \\
\text { elati } \\
\text { on }\end{array}$ & $.178^{* *}$ & $\begin{array}{r}.16 \\
3^{*}\end{array}$ & $.256^{* *}$ & $\begin{array}{l}.30 \\
9^{* *}\end{array}$ & 1 & $.230^{* * *}$ & $.288^{* *}$ & $.132^{*}$ & $\begin{array}{r}.1 \\
75 \\
* *\end{array}$ & $\begin{array}{r}.173^{*} \\
*\end{array}$ & $\begin{array}{r}.439^{*} \\
*\end{array}$ & $.160^{*}$ & $\begin{array}{r}.213^{*} \\
*\end{array}$ \\
\hline & $\begin{array}{l}\text { Sig. } \\
(2- \\
\text { taile } \\
\text { d) }\end{array}$ & .005 & $\begin{array}{r}.01 \\
1\end{array}$ & .000 & $\begin{array}{r}.00 \\
0\end{array}$ & & .000 & .000 & .040 & $\begin{array}{r}.0 \\
06\end{array}$ & .007 & .000 & .012 & .001 \\
\hline & $\mathrm{N}$ & 242 & $\begin{array}{r}24 \\
2\end{array}$ & 242 & 242 & $\begin{array}{r}24 \\
2\end{array}$ & 242 & 242 & 242 & $\begin{array}{r}24 \\
2\end{array}$ & 242 & 242 & 242 & 242 \\
\hline
\end{tabular}




\begin{tabular}{|c|c|c|c|c|c|c|c|c|c|c|c|c|c|c|}
\hline \multirow[t]{3}{*}{$\begin{array}{l}\text { Job } \\
\text { rotation/ } \\
\text { Relocati } \\
\text { on }\end{array}$} & $\begin{array}{l}\text { Pear } \\
\text { son } \\
\text { Corr } \\
\text { elati } \\
\text { on }\end{array}$ & .105 & $\begin{array}{r}.04 \\
2\end{array}$ & $.234^{* *}$ & $\begin{array}{l}.20 \\
4^{* *}\end{array}$ & $\begin{array}{l}.23 \\
0^{* *}\end{array}$ & 1 & $.212^{* *}$ & .058 & $\begin{array}{r}.1 \\
29 \\
*\end{array}$ & $\begin{array}{r}.212^{*} \\
*\end{array}$ & $\begin{array}{r}.192^{*} \\
*\end{array}$ & $.285^{* *}$ & $.191^{*}$ \\
\hline & $\begin{array}{l}\text { Sig. } \\
(2- \\
\text { taile } \\
\text { d) }\end{array}$ & .102 & $\begin{array}{r}.51 \\
1\end{array}$ & .000 & $\begin{array}{r}.00 \\
1\end{array}$ & $\begin{array}{r}.00 \\
0\end{array}$ & & .001 & .368 & $\begin{array}{r}.0 \\
45\end{array}$ & .001 & .003 & .000 & .003 \\
\hline & $\mathrm{N}$ & 242 & $\begin{array}{r}24 \\
2\end{array}$ & 242 & 242 & $\begin{array}{r}24 \\
2\end{array}$ & 242 & 242 & 242 & $\begin{array}{r}24 \\
2\end{array}$ & 242 & 242 & 242 & 242 \\
\hline \multirow[t]{3}{*}{$\begin{array}{l}\text { Workin } \\
\mathrm{g} \\
\text { Environ } \\
\text { ment }\end{array}$} & $\begin{array}{l}\text { Pear } \\
\text { son } \\
\text { Corr } \\
\text { elati } \\
\text { on } \\
\end{array}$ & $.165^{*}$ & $\begin{array}{l}.26 \\
0^{* *}\end{array}$ & $.340^{* * *}$ & $\begin{array}{l}.39 \\
5^{* *}\end{array}$ & $\begin{array}{l}.28 \\
8^{* *}\end{array}$ & $.212^{* *}$ & 1 & $.131^{*}$ & $\begin{array}{r}.2 \\
83 \\
* *\end{array}$ & $.311^{*}$ & $\begin{array}{r}.408^{*} \\
*\end{array}$ & $.344^{* *}$ & $.394^{*}$ \\
\hline & $\begin{array}{l}\text { Sig. } \\
(2- \\
\text { taile } \\
\text { d) }\end{array}$ & .010 & $\begin{array}{r}.00 \\
0\end{array}$ & .000 & $\begin{array}{r}.00 \\
0\end{array}$ & $\begin{array}{r}.00 \\
0\end{array}$ & .001 & & .041 & $\begin{array}{r}.0 \\
00\end{array}$ & .000 & .000 & .000 & .000 \\
\hline & $\mathrm{N}$ & 242 & $\begin{array}{r}24 \\
2 \\
\end{array}$ & 242 & 242 & $\begin{array}{r}24 \\
2\end{array}$ & 242 & 242 & 242 & $\begin{array}{r}24 \\
2 \\
\end{array}$ & 242 & 242 & 242 & 242 \\
\hline \multirow[t]{3}{*}{$\begin{array}{l}\text { Organiz } \\
\text { ational } \\
\text { Structur } \\
\mathrm{e}\end{array}$} & $\begin{array}{l}\text { Pear } \\
\text { son } \\
\text { Corr } \\
\text { elati } \\
\text { on }\end{array}$ & .101 & $\begin{array}{r}.10 \\
0\end{array}$ & .089 & $\begin{array}{r}.11 \\
1\end{array}$ & $\begin{array}{r}.13 \\
2^{*}\end{array}$ & .058 & $.131^{*}$ & 1 & $\begin{array}{r}.1 \\
00\end{array}$ & $.140^{*}$ & $.139^{*}$ & .020 & .096 \\
\hline & $\begin{array}{l}\text { Sig. } \\
(2- \\
\text { taile } \\
\text { d) }\end{array}$ & .119 & $\begin{array}{r}.12 \\
2\end{array}$ & .167 & $\begin{array}{r}.08 \\
5\end{array}$ & $\begin{array}{r}.04 \\
0\end{array}$ & .368 & .041 & & $\begin{array}{r}.1 \\
19\end{array}$ & .029 & .031 & .758 & .137 \\
\hline & $\mathrm{N}$ & 242 & $\begin{array}{r}24 \\
2 \\
\end{array}$ & 242 & 242 & $\begin{array}{r}24 \\
2 \\
\end{array}$ & 242 & 242 & 242 & $\begin{array}{r}24 \\
2 \\
\end{array}$ & 242 & 242 & 242 & 242 \\
\hline \multirow[t]{3}{*}{$\begin{array}{c}\text { Team } \\
\text { Spirit }\end{array}$} & $\begin{array}{l}\text { Pear } \\
\text { son } \\
\text { Corr } \\
\text { elati } \\
\text { on } \\
\end{array}$ & $.138^{*}$ & $\begin{array}{l}.23 \\
8^{* *}\end{array}$ & $.251^{* *}$ & $\begin{array}{l}.25 \\
2^{* *}\end{array}$ & $\begin{array}{l}.17 \\
5^{* *}\end{array}$ & $.129^{*}$ & $.283^{* *}$ & .100 & 1 & $.207^{*}$ & $\begin{array}{r}.209^{*} \\
*\end{array}$ & $.208^{* *}$ & $\begin{array}{r}.274^{*} \\
*\end{array}$ \\
\hline & $\begin{array}{l}\text { Sig. } \\
(2- \\
\text { taile } \\
\text { d) }\end{array}$ & .032 & $\begin{array}{r}.00 \\
0\end{array}$ & .000 & $\begin{array}{r}.00 \\
0\end{array}$ & $\begin{array}{r}.00 \\
6\end{array}$ & .045 & .000 & .119 & & .001 & .001 & .001 & .000 \\
\hline & $\mathrm{N}$ & 242 & $\begin{array}{r}24 \\
2 \\
\end{array}$ & 242 & 242 & $\begin{array}{r}24 \\
2 \\
\end{array}$ & 242 & 242 & 242 & $\begin{array}{r}24 \\
2 \\
\end{array}$ & 242 & 242 & 242 & 242 \\
\hline \multirow[t]{3}{*}{$\begin{array}{l}\text { Reward } \\
\text { - } \\
\text { Punish } \\
\text { ment } \\
\text { Approa } \\
\text { ch }\end{array}$} & $\begin{array}{l}\text { Pear } \\
\text { son } \\
\text { Corr } \\
\text { elati } \\
\text { on } \\
\end{array}$ & $.226^{* *}$ & $\begin{array}{l}.20 \\
9^{* *}\end{array}$ & $.176^{* *}$ & $\begin{array}{l}.27 \\
1^{* *}\end{array}$ & $\begin{array}{l}.17 \\
3^{* *}\end{array}$ & $.212^{* *}$ & $.311^{* *}$ & $.140^{*}$ & $\begin{array}{r}.2 \\
07 \\
* *\end{array}$ & 1 & $.436^{*}$ & $.190^{* *}$ & $.361_{*}^{*}$ \\
\hline & $\begin{array}{l}\text { Sig. } \\
(2- \\
\text { taile } \\
\text { d) }\end{array}$ & .000 & $\begin{array}{r}.00 \\
1\end{array}$ & .006 & $\begin{array}{r}.00 \\
0\end{array}$ & $\begin{array}{r}.00 \\
7\end{array}$ & .001 & .000 & .029 & $\begin{array}{r}.0 \\
01\end{array}$ & & .000 & .003 & .000 \\
\hline & $\mathrm{N}$ & 242 & $\begin{array}{r}24 \\
2\end{array}$ & 242 & 242 & $\begin{array}{r}24 \\
2\end{array}$ & 242 & 242 & 242 & $\begin{array}{r}24 \\
2 \\
\end{array}$ & 242 & 242 & 242 & 242 \\
\hline \multirow[t]{3}{*}{$\begin{array}{l}\text { Stress } \\
\text { Manage } \\
\text { ment }\end{array}$} & $\begin{array}{l}\text { Pear } \\
\text { son } \\
\text { Corr } \\
\text { elati } \\
\text { on } \\
\end{array}$ & $.330^{* * *}$ & $\begin{array}{l}.33 \\
4^{* *}\end{array}$ & $.273^{* *}$ & $\begin{array}{l}.38 \\
0^{* *}\end{array}$ & $\begin{array}{l}.43 \\
9^{* *}\end{array}$ & $.192^{* * *}$ & $.408^{* * *}$ & $.139^{*}$ & $\begin{array}{r}.2 \\
09 \\
* *\end{array}$ & $\begin{array}{r}.436^{*} \\
*\end{array}$ & 1 & $.381^{* * *}$ & $.371^{*}$ \\
\hline & $\begin{array}{l}\text { Sig. } \\
(2- \\
\text { taile } \\
\text { d) }\end{array}$ & .000 & $\begin{array}{r}.00 \\
0\end{array}$ & .000 & $\begin{array}{r}.00 \\
0\end{array}$ & $\begin{array}{r}.00 \\
0\end{array}$ & .003 & .000 & .031 & $\begin{array}{r}.0 \\
01\end{array}$ & .000 & & .000 & .000 \\
\hline & $\mathrm{N}$ & 242 & $\begin{array}{r}24 \\
2\end{array}$ & 242 & 242 & $\begin{array}{r}24 \\
2\end{array}$ & 242 & 242 & 242 & $\begin{array}{r}24 \\
2\end{array}$ & 242 & 242 & 242 & 242 \\
\hline
\end{tabular}




\begin{tabular}{|c|c|c|c|c|c|c|c|c|c|c|c|c|c|c|}
\hline \multirow[t]{3}{*}{$\begin{array}{l}\text { Commu } \\
\text { nication } \\
\text { with } \\
\text { Senior } \\
\text { Manage } \\
\text { ment }\end{array}$} & $\begin{array}{l}\text { Pear } \\
\text { son } \\
\text { Corr } \\
\text { elati } \\
\text { on } \\
\end{array}$ & $.207^{* * *}$ & $\begin{array}{r}.10 \\
7\end{array}$ & $.236^{* *}$ & $\begin{array}{l}.31 \\
5^{* *}\end{array}$ & $\begin{array}{r}.16 \\
0^{*}\end{array}$ & $.285^{\text {** }}$ & $.344^{* *}$ & .020 & $\begin{array}{r}.2 \\
08 \\
* *\end{array}$ & $.190^{*}$ & $.381_{*}^{*}$ & 1 & $.386_{*}^{*}$ \\
\hline & $\begin{array}{l}\text { Sig. } \\
\text { (2- } \\
\text { taile } \\
\text { d) }\end{array}$ & .001 & $\begin{array}{r}.09 \\
7\end{array}$ & .000 & $\begin{array}{r}.00 \\
0\end{array}$ & $\begin{array}{r}.01 \\
2\end{array}$ & .000 & .000 & .758 & $\begin{array}{r}.0 \\
01\end{array}$ & .003 & .000 & & .000 \\
\hline & $\mathrm{N}$ & 242 & $\begin{array}{r}24 \\
2 \\
\end{array}$ & 242 & 242 & $\begin{array}{r}24 \\
2 \\
\end{array}$ & 242 & 242 & 242 & $\begin{array}{r}24 \\
2 \\
\end{array}$ & 242 & 242 & 242 & 242 \\
\hline \multirow[t]{3}{*}{$\begin{array}{l}\text { Work } \\
\text { Perform } \\
\text { ance } \\
\text { Evaluati } \\
\text { on } \\
\text { System }\end{array}$} & $\begin{array}{l}\text { Pear } \\
\text { son } \\
\text { Corr } \\
\text { elati } \\
\text { on } \\
\end{array}$ & $.249^{* * *}$ & $\begin{array}{l}.17 \\
5^{* *}\end{array}$ & $.318^{* *}$ & $\begin{array}{l}.38 \\
1^{* *}\end{array}$ & $\begin{array}{l}.21 \\
3^{* *}\end{array}$ & $.191^{\text {*** }}$ & $.394^{* *}$ & .096 & $\begin{array}{r}.2 \\
74 \\
* *\end{array}$ & $.361_{*}^{*}$ & $.371_{*}^{*}$ & $.386^{* * *}$ & 1 \\
\hline & $\begin{array}{l}\text { Sig. } \\
\text { (2- } \\
\text { taile } \\
\text { d) }\end{array}$ & .000 & $\begin{array}{r}.00 \\
6\end{array}$ & .000 & $\begin{array}{r}.00 \\
0\end{array}$ & $\begin{array}{r}.00 \\
1\end{array}$ & .003 & .000 & .137 & $\begin{array}{r}.0 \\
00\end{array}$ & .000 & .000 & .000 & \\
\hline & $\mathrm{N}$ & 242 & $\begin{array}{r}24 \\
2 \\
\end{array}$ & 242 & 242 & $\begin{array}{r}24 \\
2 \\
\end{array}$ & 242 & 242 & 242 & $\begin{array}{r}24 \\
2 \\
\end{array}$ & 242 & 242 & 242 & 242 \\
\hline
\end{tabular}

(Field Survey, 2020)

From Table 15 it can be revealed that remuneration and job security are closely related to each other with correlation coefficient value of 0.505 . It shows that if an employee gets more remuneration $\mathrm{s} / \mathrm{he}$ feels more secured. Likewise, Correlation Coefficient varies from Work Performance Evaluation System-Organizational structure (0.096) to Job security -Remuneration (0.505).

\subsubsection{Employee Adjustment Act and Government Employees}

Perception of Government official on adjustment process is shown in Table 16.

Table 16: Officials Perception on their Adjustment Act and pay Policy

\begin{tabular}{|l|c|c|c|}
\hline & N & Mean & Std. Deviation \\
\hline Officials Adjustment Process & 242 & 2.7975 & 1.00016 \\
\hline $\begin{array}{l}\text { Amendment in inter province and } \\
\text { inter local level transfer }\end{array}$ & 242 & 4.0372 & .88008 \\
\hline Current Pay Increment System & 242 & 2.6860 & 1.03894 \\
\hline $\begin{array}{l}\text { Newly developed Organizational } \\
\text { frame }\end{array}$ & 242 & 2.8306 & .90194 \\
\hline $\begin{array}{l}\text { Facilities of growth of Career in Act } \\
\text { Amendment in Promotion and Job } \\
\text { Rotation Approach }\end{array}$ & 242 & 3.0826 & 2.81692 \\
\hline $\begin{array}{l}\text { Amendment in current Organizational } \\
\text { Structure and Remuneration-Pay } \\
\text { Policy }\end{array}$ & 242 & 4.1818 & .78314 \\
\hline
\end{tabular}

(Field Survey, 2020)

It shows that amendment is necessary by the government to motivate employees who are the real pillar to implement federal constitution of Nepal. 


\section{CONCLUSION :}

Government level employee job satisfaction in changed federal structure of Nepal seems very pivotal in nature because government employees play crucial role for people's daily life activities. In this context Bhojpur district of Nepal was selected for research to find government level employee job satisfaction in changed scenario in political system.

Federal and provincial level employees expressed just satisfied with mean value of 3.08 and 3.27 respectively while local level employees expressed dissatisfaction with mean value of 2.82. As from Key Informant Interview (KII) it has been disclosed that local level government is not matured and less professional along with micro political debates has demotivated government employees. Lack of job rotation gadget in local and provincial degree and their recommendation to amend for inter province and inter nearby degree switch (4.03) illustrates amendment of transfer mechanism in the federal system. However present leave system, job position and authority seems satisfactory. Present work performance assessment device and decision-making method in the workplaces seems not precise in exercise. From the result it is able to be stated that those parameters need to be progressed to decorate overall performance of government personnel.

Major elements affecting activity satisfaction seem to be advertising and career development ( $\mathrm{RII}=0.933)$ observed via task training $(\mathrm{RII}=0.926)$, working environment $(\mathrm{RII}=0.922)$, team spirit $(\mathrm{RII}=0.919)$ and proper work performance assessment gadget $(\mathrm{RII}=0.909)$. It indicates that appropriate advertising mechanism with proper working environment and schooling with right crew and proper evaluation can enhance performance of presidency personnel. The results confirmed that remuneration, job protection, work existence balance, organizational structure, job rotation, praise-punishment technique, pressure management, verbal exchange with management can play mild role for development of performance of a government employee.

Employee adjustment process (2.79) appears dissatisfactory from the attention of government personnel. As in step with KII it turned into forcefully accomplished irrespective of emotions of personnel so that most of the government employees opined that it isn't always best from diverse perspectives. From the end result it's far seen that employees aren't happy with gift task rotation gadget and assume modification for inter province and inter nearby authority's degree switch. Present earnings increment mechanism (2.68) is likewise no longer pleasant on account that rate inflation is dominant in market due to political, social and economic turbulences. From the end result its miles seen that newly formed organizational structure and wage policy is anticipated to be amended for better overall performance of government degree employees.

\section{RECOMMENDATIONS :}

Following points are recommended:

- The Remuneration of government employees is very less as compared to private sector and market price inflation. So, it is recommended that government should increase salary and benefits by considering price inflation and market condition.

- Job training should be included in routine manner so that every employee become competent and deliver their services effectively and in an efficient manner.

- Job rotation and actual work performance evaluation system should be initiated to measure actual productivity of employees.

- Organizational structure and transfer system should be amended considering opinion of all three tiers of government employees.

- Promotion mechanism and career development planning should be clear and easy so that competent employees enter inside government system making effective service delivery.

- Decision making system in offices should be participatory and transparent so that every employee of organization takes ownership of the decision and implements in the field.

- Salary increment mechanism should be scientific addressing changed market price in the society so that every employee can focus only on work and productivity.

\section{REFERENCES :}

[1] Government of Nepal. (2015). Constitution of Nepal . Kathmandu: Ministry of Law, Justice and Parliamentary Affairs. http://www.moljpa.gov.np/ 
[2] Government of Nepal. (2017). Employee Readjustment Act. Kathmandu: Ministry of Federal Affairs and Administration. https://www.lawcommission.gov.np/en/archives/category/documents/prevailinglaw/constitution/constitution-of-nepal

[3] The Himalayan Times. (2019, March 28). Retrieved January 06, 2020, from https://thehimalayantimes.com/nepal/civil-servant-adjustment-process-concludes/

[4] Paudel, B. (2020). Satisfaction, Study on Job Satisfaction of Civil Engineers in Gandaki Provincial Government. Kathmandu: Tribhuwan University. www.tu.edu.np

[5] Sageer, A., Rafat, D., \& Agarwal, P. (2012). Identification of Variables Affecting Employee Satisfaction and Their Impact on the Organization. IOSR Journal of Business and Management, 5(1), 32-39.

[6] More, B., \& Padmanabhan, H. K., (2017). A Comparative Study on Employees Job Satisfaction Level Using Herzberg Two Factor and Maslowes Need Theory With Reference To Manufacturing Industry. International Journal of Research and Innovation in Social Science (IJRISS), 1(1), 3338 .

[7] Mishra, A. K. (2018). Assessment of Human Resource Capacity of Construction Companies in Nepal. J Adv Res Jour Mass Comm, 5(4), 14-25.

[8] Mishra, A. K., \& Aithal P. S., (2021). Foreign Aid Contribution for the Development of Nepal. International Journal of Management, Technology, and Social Sciences (IJMTS), 6(1), 162-169.

[9] Mishra, A. K., \& Aithal, P. S., (2021). Foreign Aid Movements in Nepal. International Journal of Management, Technology, and Social Sciences (IJMTS), 6(1), 142-161.

[10] Hong, L. c., Hamid, N. I., \& Salleh, N. M. (2013). A Study on the Factors Affecting Job Satisfaction amongst Employees of a Factory in Saremban, Malaysia. Business Management Dynamics, 3(1), $26-40$.

[11] Kumari, J. P. (2016). Conceptual Framework:Factors Affecting for Workplace Job Performances. Journal of Business and Management, 18(10), 99-101.

[12] Hee, O. C., Yan, L. H., Rizal, A. M., Kowang, T. O., \& Fei, G. C. (2018). Factors Influencing Employee Job Satisfaction: A Conceptual Analysis. International Journal of Academic Research in Business and Social Sciences, 8(6), 331-340.

[13] Singh, A. S., \& Masuku, M. B. (2014). Sampling Techniques and Determination of Sample Size in Applied Statistics Research: An Overview. International Journal of Economics, Commerce and Management, II(11), 1-22.

[14] Somiah, M. K. (2015). http://shodhganga.inflibnet.ac.in/bitstream/10603/2589/12/12_ chapter\%203.pdf. Retrieved January 05, 2020

[15] Cortina, J. M. (1993). What is coefficient alpha? An examination of theory and applications. Journal of Applied Psychology, 78(1), 98-104. 